\title{
Energy budgets for juvenile Pacific whiteleg shrimp Litopenaeus vannamei fed different diets
}

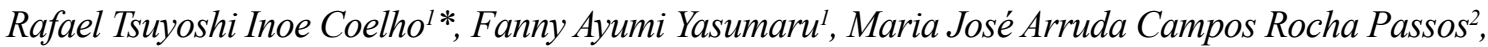 \\ Vicente Gomes ${ }^{2}$, Daniel Lemos ${ }^{1}$
}

\author{
${ }^{1}$ Instituto Oceanográfico da Universidade de São Paulo, Aquaculture Laboratory \\ (Praça do Oceanográfico, 191, sala 111B - CEP: 05508-120. Cidade Universitária, São Paulo (SP) - Brazil) \\ ${ }^{2}$ Instituto Oceanográfico da Universidade de São Paulo, Laboratory of Ecophysiology of Marine Organisms \\ (Praça do Oceanográfico, 191, sala 109 - CEP: 05508-120. Cidade Universitária, São Paulo (SP) - Brazil) \\ *Corresponding author: tsuyoshi.rafael@gmail.com
}

\section{Abstract}

Energy budgets for juvenile Pacific whiteleg shrimp, Litopenaeus vannamei (1.7-4.0 g ) fed with different diets were assessed. The energy partitioning between growth, respiration, ammonia excretion, feces and exuvia was calculated to estimate for total food energy intake. Shrimp oxygen consumption and ammonia excretion were quantified in sealed chambers $\left(25^{\circ} \mathrm{C}, 34 \mathrm{ppt}\right)$. Energy allocated for growth and feces were obtained from the wet combustion of whole body and feces samples, exuvia was estimated as $10 \%$ growth energy. Three diets were tested: 100\% chopped fish (Fish), 100\% commercial feed (Feed), and 50-50\% chopped fish and commercial feed (Mix). Most of the energy from the diets was channeled into respiration (49.7-70.5\%). Shrimp fed the Feed diet used more energy in growth (24.4\%) than those fed Mix (13.4\%) or Fish diets (13.2\%), either in absolute (joule) or relative (\% of ingested energy) terms. Conversely, energy loss as ammonia excretion was lower in shrimp fed Feed (1.0\%) compared to shrimp fed Mix (4.2\%) or Fish diets (7.8\%). Less energy was lost in feces by shrimp fed Fish diet (7.3\%) compared to Mix (20.2\%) and Feed diets $(22.2 \%)$. The calculated energy intake by shrimp fed Fish, Mix and Feed were $0.995,1.100$, and $1.255 \mathrm{~kJ}^{\text {ind }} \mathrm{day}^{-1}$, respectively. According to the O:N atomic ratios (oxygen consumed to nitrogen excreted), protein tented to

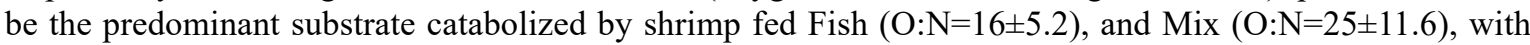
increasing use of carbohydrates and/or lipids in the Feed ( $\mathrm{O}: \mathrm{N}=74 \pm 37.3)$. Results suggest diet composition may affect energy budget and partitioning differently between metabolism and growth either in absolute or relative terms, as shrimp fed Fish and Mix diets used protein as main substrate for metabolism, whereas shrimp fed Feed diet channeled protein for growth, and lipids and carbohydrates for other metabolic functions.

Descriptors: Bioenergetics, Shrimp, Energy partitioning, Growth, Feed efficiency, Litopenaeus vannamei.

\section{INTRODUCTION}

The efficient use of ingested food energy between metabolism and growth may be a requisite for the successful existence of any species. Food availability and quality for shrimp in either natural or farming environment may vary over time and so the efficiency of energy allocation in metabolic processes and biomass accumulation. The ability of shrimp species in using different food substrates (protein, lipid and carbohydrates) in body energy flow may be an advantage in exploring food conditions in fulfilling physiological needs.

Submitted on: 31/December/2018

Approved on: 3/May/2019

http://dx.doi.org/10.1590/S1679-87592019024306701
The energy acquired via food intake is channeled between the vital process of activities of growth, metabolism, ammonia excretion, feces, and, in the case of shrimp, molting (Jobling, 1993; Lemos and Phan, 2001; Petrusewicz and Macfadyen, 1970). The partitioning of the ingested energy between these processes may depend on variables such as shrimp life stage (Lemos and Phan, 2001; Maldonado et al., 2009), dietary composition (Gauquelin et al., 2007; JiménezYan et al., 2006; Suárez et al., 2009; Wang et al., 2006), and environmental factors (Rosas et al., 2001; Su et al., 2010; Wang et al., 2006; Yan et al., 2007; Ye et al., 2009). The ratio of energy partitioned between growth and other metabolic processes may represent the efficiency of energy utilization (Duncan and Klekowski, 1975). 
Furthermore, the $\mathrm{O}: \mathrm{N}$ atomic ratio (oxygen respired to nitrogen excreted) is often employed in energetic studies as an indicator of the organic substrate, i.e., lipids, carbohydrates or proteins, that is metabolized for energy production (Ding et al., 2014; Gauquelin et al., 2007; Lemos and Phan, 2001; Rosas et al., 1996). Theoretical $\mathrm{O}: \mathrm{N}$ atomic ratios can range from 3 to 16 for the catabolism of pure protein, 50 to 60 for equal catabolism of lipids and proteins, and values above 60 for predominance of lipids and carbohydrates as substrate (Comoglio et al., 2004; Mayzaud and Conover, 1988).

Recently, interest in energy partitioning between growth and metabolism has increased in commercially farmed shrimp species such as Litopenaeus vannamei (Su et al., 2010; Wang et al., 2006; Yan et al., 2007; Zhu et al., 2004) and Penaeus monodon (Ye et al., 2009) fed compound diets. However, it is still unclear how dietary nutrient composition may affect energy partitioning between metabolism and growth, either in absolute or relative ( $\%$ ingested energy) terms. Hence, the objective of the present study was to estimate the energy partitioning between vital processes in juvenile Litopenaeus vannamei fed different diets (fish fillet, commercial feed or a mixture of both). The O:N atomic ratio was also calculated in order to assess the use of different substrates for energy production, and how dietary protein is used for growth and other metabolic processes.

\section{MATERIALS AND METHODS}

\section{EXPERIMENTAL SET-UP, DIETS, AND FEEDING}

Pacific white shrimp Litopenaeus vannamei postlarvae were purchased from a commercial hatchery (Aquatec Aquacultura Ltda., Canguaretama, RN, Brazil) and reared in a biofloc system at $25^{\circ} \mathrm{C}$ and salinity 34 . Juvenile shrimp (1.7 g- mean weight) were transferred to three $75-\mathrm{L}$ experimental tanks at a density of 180 ind $\mathrm{m}^{-2}(55$ individuals per tank). Tanks were provided with continuous aeration and connected to a recirculating water system equipped with a skimmer, a heater, a submersible pump, and a 150-L header tank that served water to each experimental tank, with a flow of $3.5 \mathrm{~L} \mathrm{~min}^{-1}$. Occasionally, freshwater was added to the system to correct for changes in salinity due to evaporation. A settling tube system was installed for feces collection at the bottom of each experimental tank, this external management did not disturb shrimp. Water salinity, temperature and dissolved oxygen concentration were measured daily with an electronic probe (YSI Model 85, Yellow Springs, OH, USA). Total dissolved ammonia concentration was measured weekly with a colorimetric kit (Ammonia/Ammonium test, Tropic 28110, Tropic Marin, Wartenberg, Germany). Mean water quality values controlled during the 40 days of experiment were temperature $25.6^{\circ} \mathrm{C}$, salinity 33.7 , dissolved oxygen concentration $5.48 \mathrm{mg} \mathrm{L}^{-1}$, and ammonia $0.08 \mathrm{mg} \mathrm{L}^{-1}$, to be similar as performed in respirometric determinations, the values were the same for all tanks of the experiment.

Three diets were tested: chopped $(<0.5 \mathrm{~cm})$ Lutjanidae fish fillet (Fish); commercial extruded shrimp feed (Feed) (Potimar 35 EXT, Guabi Nutrição e Saúde Animal S.A., Campinas, SP, Brazil); and 50$50 \%$ mix of fish fillet and commercial feed (Mix). The proximate composition of the Fish and Feed diets were analyzed according to standard methods (AOAC, 2005). Values for the Mix diet were calculated as $50-50 \%$ of fish and feed values on dry matter basis (Table 1). Dry matter was determined by drying the samples at $70^{\circ} \mathrm{C}$ until constant weight (approximately $72 \mathrm{~h}$ ); ash content by incinerating the samples at $600^{\circ} \mathrm{C}$ for $4 \mathrm{~h}$; and crude fat by petroleum ether extraction (ST255 Soxtec, Foss, Denmark). Prior to extraction, the commercial feed samples were hydrolyzed in $4 \mathrm{M}$

Table 1. Proximate composition (\% "as is") values of the three test diets fed to juvenile Pacific whiteleg shrimp, Litopenaeus vannamei. Values expressed as mean (s.d.).

\begin{tabular}{lccccc}
\hline Diets & Moisture (\%) & Crude Protein $(\%)$ & Crude Fat $(\%)$ & Ash (\%) & NFE+CF* \\
\hline Fish & $78.85(0.33)$ & $18.92(0.03)$ & $1.01(0.34)$ & $1.18(0.22)$ & 1.04 \\
Mix & 64.53 & 22.14 & 2.39 & 3.65 & 7.29 \\
Feed & $7.27(0.89)$ & $35.00(0.20)$ & $7.93(0.23)$ & $13.55(0.86)$ & 36.25 \\
\hline
\end{tabular}

Fish: chopped fish fillet $(<0.5 \mathrm{~cm})$

Mix: $50-50 \%$ fish and commercial feed (dry matter basis). Mean values calculated as 50\% from fish and 50\% from the commercial diet ("as is") Commercial feed: extruded shrimp feed (Potimar 35 EXT, Guabi Nutrição e Saúde Animal S.A., Campinas, São Paulo, Brazil)

* Nitrogen-free extract (NFE) and crude fiber $(\mathrm{CF})$ calculated as $100-$ (protein + fat + ash + moisture). 
$\mathrm{HCl}$ for $1 \mathrm{~h}$. For crude protein ( $\mathrm{N}$ x 6.25), samples were digested using block digestion during 1 hour and $420^{\circ} \mathrm{C}$ with concentrated sulfuric acid $\left(\mathrm{H}_{2} \mathrm{SO}_{4}\right)$ and catalyzers (copper sulfate, titanium oxide, potassium sulfate) prior steam distillation (Model Kjeltec 8200, Foss, Denmark).

Shrimp was fed $5 \%$ body weight every morning using trays (trays prevent food from being carried by the water flow). As fresh fish had a large amount of moisture in its composition, the amount of Fish and Mix diets were corrected to fish fillet wet weight to be comparable with Feed diet in terms of dry weight daily offered. Shrimp were individually weighed to determine initial and final weight, and group-weighed every two weeks to adjust feeding rate.

\section{ENERGY BUDGET}

Energy partitioning in juvenile L. vannamei was calculated according to the equation used for crustaceans (Lemos and Phan, 2001; Petrusewicz and Macfadyen, 1970):

$C=P+R+U+F+E$, where $C$ is the ingested dietary energy partitioned between growth $(P)$, respiration $(R)$, ammonia excretion $(U)$, feces $(F)$, and exuvia $(E)$. The equation terms were measured and converted with adequate coefficients in energy units, Joules (J), and also calculated in relative terms, where the ingested energy corresponds to $100 \%$ being divided according to the demand $(100 \%=P+R+U+F+E)$ in the energy budget equation.

Energy for $P$ was measured as the difference between the shrimp final and initial wet weight. Energy content in shrimp samples was determined by wet combustion (Karzinkin and Tarkovskaya, 1964) and expressed as J $\mathrm{mg}^{-1}$ dry matter (DM). To calculate energy channeled for growth, mean daily weight gain (DM basis) during 14 days (last 2 weeks of experiment) was multiplied by the energy content of whole body shrimp samples.

Energy consumed with $R$ and $U$ were determined in sealed chambers (respirometers) (Rocha et al., 2005). The respirometers consisted in cylindrical acrylic chambers that included screw cap to introduce a shrimp, one large orifice (15mm diameter) for water renewal and sample collection and a minor orifice (1 $1 \mathrm{~mm}$ diameter) was used to expel eventual air bubbles during chamber sealed by pressing a cover in large orifice. In addition to the shrimp fed the test diets, a group was subjected to $48 \mathrm{~h}$ fasting before the respirometric test (Unfed). For each diet treatment 20 shrimp (1.5-3.9g) were employed in individual $R$ and $U$ determinations. One-hour before the respirometry test, shrimp were fed $a d$ libitum their respective test diets, except the Unfed group.
Then, shrimp were individually placed in 1-L respirometer (large enough to allow sudden and free movement of shrimp) with filtered seawater $(1 \mu \mathrm{m})$, at salinity 34 , $25^{\circ} \mathrm{C}$, and constant water flow and acclimated for $3 \mathrm{~h}$ with minimum disturb minimize stress (Carvalho and Phan, 1997). The water flow was then stopped, water samples were collected (initial), and then the chamber was sealed for approximately $1 \mathrm{~h}$. Next, the chamber was opened, and water sampled (final). Dissolved oxygen concentration and total ammonia nitrogen (TAN) were determined in both initial and final water samples to calculate consumption/ excretion by difference. Oxygen levels in chambers were never under $70 \%$ saturation after incubation to avoid hypoxic stress and the tests were always performed in the same time zone of the day, in order to minimize the influence of exogenous factors that could affect shrimp metabolism (Rocha et al., 2001). Dissolved oxygen consumption ( $\mathrm{ml} \mathrm{O}_{2} \mathrm{~g}^{-1}$ shrimp live weight $\mathrm{h}^{-1}$ ) was determined by application of the Winkler method (Grasshoff et al., 1983) and total ammonia nitrogen excretion ( $\mu \mathrm{mol}$ TAN g ${ }^{-1}$ shrimp live weight $\mathrm{h}^{-1}$ ) by the colorimetric method (Koroleff, 1970) with adaptation to $10 \mathrm{~mm}$ path length cuvettes read. Initial water samples were collected in duplicate for determination of each parameter and final water sample was collected individually per respirometer. Shrimp oxygen consumption $\left(\mathrm{ml} \mathrm{O}_{2} \mathrm{~g}^{-1} \mathrm{~h}^{-1}\right)$ and ammonia excretion $(\mu \mathrm{mol}$ TAN $\mathrm{g}^{-1} \mathrm{~h}^{-1}$ ), live weight basis, were then converted into energy values (Phan et al., 1993); oxycalorific coefficient by Gnaiger (1983), $14.06 \mathrm{~J}$ lost as work per gram of oxygen consumed. For ammonia excretion, $24.86 \mathrm{~J}$ was considered lost as per mg of TAN (Elliott and Davison, 1975). Mean daily energy expenditure rates (24h) were extrapolated from the values measured per hour. Molting stage of shrimp used in respirometry was not determined though individuals at postmolt were not employed. Thus, metabolic rates may be considered average values of intermolt and premolt shrimp that represents $>80 \%$ of the interval between molting.

Shrimp feces $(F)$ were sampled during the last two weeks of experiment. Settling tubes installed in rearing tanks were cleaned in the morning prior to feeding. Feces samples were collected twice a day (two and four hours after the start of feeding), based in a transit time of $L$. vannamei (Beseres et al., 2005) and the period to decantation of feces in settling tubes. Feces remained maximum two hours immersed in settling tubes prior to sampling to minimize leaching. 
Collected samples were gently rinsed with distilled water to eliminate excess salt, filtered on filter paper with the aid of a vacuum pump and kept frozen at $-20^{\circ} \mathrm{C}$ until analysis. Energy content in shrimp feces samples was determined by wet combustion (Karzinkin and Tarkovskaya, 1964) and expressed as $\mathrm{J} \mathrm{mg}^{-1}$ DM. Energy expenditure in feces $(F)$ was calculated as the daily mean feces weight released in each treatment tank divided by the number of individuals ( $\mathrm{mg}$ feces $\mathrm{g}^{-1}$ shrimp day-1), and finally multiplied by the feces energy content ( $\mathrm{J} \mathrm{mg}^{-1}$ feces, dry matter).

Energy expenditure with exuviation $(E)$ was not determined in the present study, and literature value of $10 \%$ of the energy allocated in growth per individual was adopted (Yan et al., 2007; Zhu et al., 2004).

In order to compare energy budgets from different dietary treatments, a common shrimp weight was used to calculate the relative energy expenditure (\%) corresponding to $3.5 \mathrm{~g}$. This value corresponded to the average weight of the shrimps in the main period of data collection (feces collection, growth data and respirometry tests).

\section{ON ATOMIC RATIO}

The O:N atomic ratio (atoms of oxygen consumed per atoms of nitrogen excreted) were calculated for fasted shrimp (48h) and shrimp fed the test diets. Nitrogen value was derived from excreted ammonia, as it represents the majority of the metabolic nitrogen in crustaceans. Mean oxygen consumption and ammonia excretion rates expressed as $\mathrm{mL} \mathrm{O}_{2} \mathrm{~g}^{-1} \mathrm{~h}^{-1}$ and $\mu$ mol TAN $\mathrm{g}^{-1} \mathrm{~h}^{-1}$, respectively, were converted to the number of atoms and the $\mathrm{O}: \mathrm{N}$ atomic ratio was calculated.

\section{STATISTICAL ANALYSIS}

All data were previously submitted to normality and homoscedastic tests, significant differences in the means between dietary treatments were evaluated using one-way analysis of variance (ANOVA), and significant difference between means were detected by the post-hoc Tukey test. Probabilities were considered significant at $p<0.05$.

\section{RESULTS}

Shrimp growth is presented in Figure 1. After the experimental period, mean wet weight of shrimp fed the Fish and Mix diets were similar (3.38 g and $3.60 \mathrm{~g}$, respectively), whereas mean wet weight of shrimps fed the Feed diet a significantly higher $(p<0.05)$ weight $(4.24 \mathrm{~g})$ at the end of the 40 days of feeding trial.

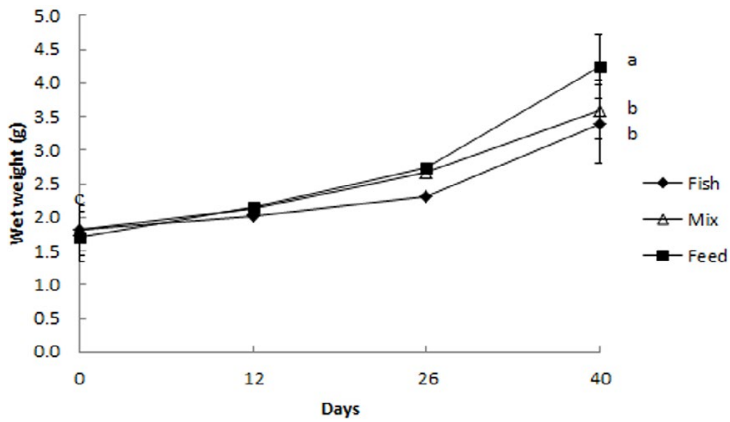

Figure 1. Mean wet weight of juvenile Pacific whiteleg shrimp, Litopenaeus vannamei, fed three diets (Fish: chopped fish fillet; Mix: $50-50 \%$ fish fillet and commercial feed; Feed: commercial feed) for 40 days. $50-50 \%$ Vertical bars in the initial and final weight indicate standard deviation of the weight of the individuals. ( $\mathrm{n}=55$ initial and $n=40$ final) Different superscript letters indicate significant difference between means $(p<0.05)$. Shrimp were group-weighed in the intermediate weighing.

Mean specific $\mathrm{O}_{2}$ consumption values did not differ $(p>0.05)$ between diets though it was significantly lower $(p<0.05)$ in fasted individuals (Figure 2A). Mean specific TAN excretion was reduced in shrimp fed the Feed diet and are significantly lower $(p<0.05)$ to other diets, Mix and Unfed treatments did not show any statistical difference among them, while the fish diet was significantly higher $(p<0.05)$ than all the others (Figure 2B).

Diet treatments also produced difference in moisture and energy content of shrimp (Table 2). Moisture content in shrimp body fed Fish diet (78.5\%) was higher than in shrimp fed Mix (75.9\%) or Feed diet (74.1\%), In contrast, energy content in shrimp tissue fed Feed diet was higher $\left(20.72 \pm 2.05 \mathrm{~J} \mathrm{mg}^{-1} \mathrm{DM}\right)$ than in shrimp fed Fish or Mix diets $\left(17.24 \pm 0.66\right.$ and $16.40 \pm 1.13 \mathrm{~J} \mathrm{mg}^{-1}$ DM, respectively). In shrimp feces, energy content was higher in shrimp fed Mix and Feed diets (11.67 \pm 0.71 and $12.30 \pm 0.79 \mathrm{~J} \mathrm{mg}^{-1} \mathrm{DM}$, respectively) than in Fish diet (8.37 $\left.\pm 1.13 \mathrm{~J} \mathrm{mg}^{-1} \mathrm{DM}\right)$.

Energy partitioning in terms of kiloJoules and as percentage of the energy intake is presented in Figure 3. Total energy intake was calculated as the sum of the energy used for $P, R, U, F$, and $E$ in shrimp fed the three test diets. Though shrimp metabolism consumed similar energy in absolute terms for Fish, Mix and Feed diets (0.701; 0.666; $0.624 \mathrm{~kJ} \mathrm{day}^{-1}$, respectively), in relative terms ingested energy expended in metabolism showed diet effects, ranging between 70.5 , 60.6, and $49.7 \%$ for shrimp fed Fish, Mix and Feed diets, respectively. The energy channeled into $P$ was increased in shrimp fed the Feed diet $(24.4 \%)$ in comparison to individuals fed Fish (13.2\%) or Mix (13.4\%) diets. 

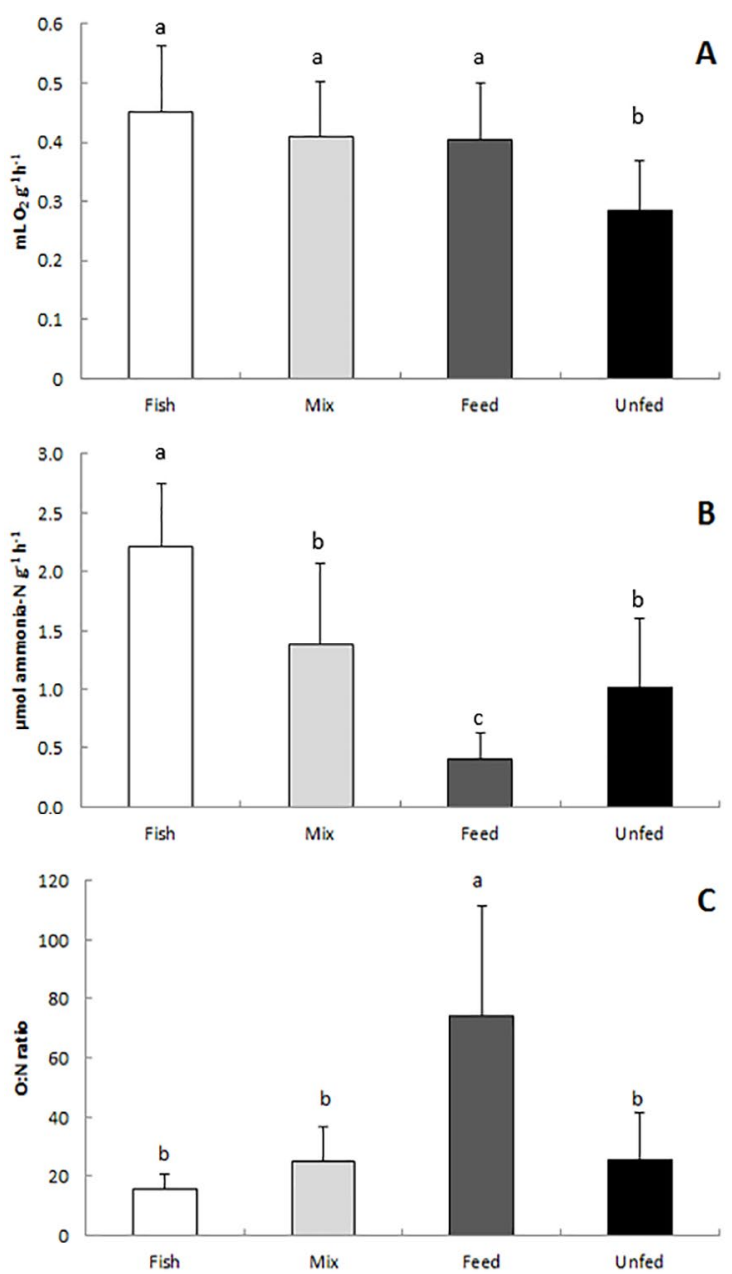

Figure 2. Oxygen consumption (A), ammonia excretion (B), and O:N ratio $(\mathrm{C})$ in juvenile Pacific whiteleg shrimp Litopenaeus vannamei fed different diets: chopped fish fillet (Fish), 50\% chopped fish fillet $50 \%$ commercial feed (Mix), commercial feed (Feed), and fasted (48 h) (Unfed). Values expressed as mean, vertical bar indicate standard deviation. Different superscript letters denote significant difference $(p<0.05)$. $\mathrm{n}=20$.

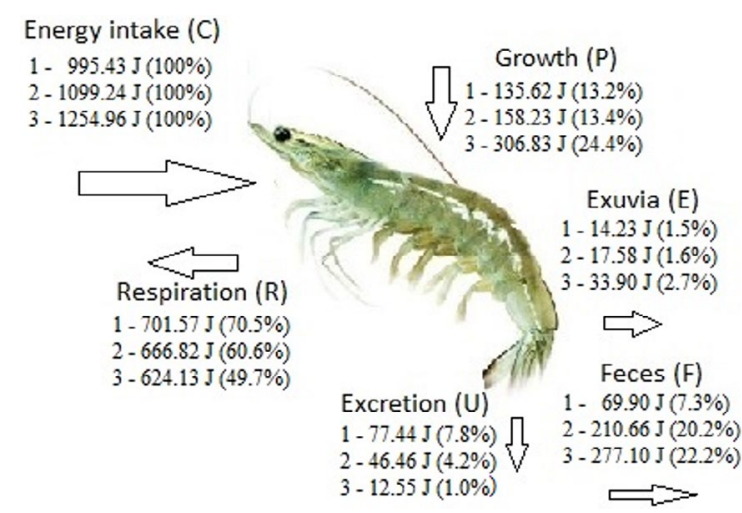

Figure 3. Estimated energy partitioning of juvenile Pacific whiteleg shrimp Litopenaeus vannamei reared in laboratory and fed three dietary treatments (1 - Fish: chopped fish fillet; 2 - Mix: 50-50\% fish fillet and commercial feed; 3 - Feed: commercial feed). Values expressed as Joule per individual (theorical weight $3.5 \mathrm{~g}$ ) per day and percentage of ingestion.

For $U$, more energy was expended by shrimp fed Fish diet $(7.8 \%)$, followed by Mix diet (4.2\%) and Feed diet $(1.0 \%)$. On the other hand, energy expended in $F$ was higher in shrimp fed Feed diet $(22.2 \%)$ and Mix diet $(20.2 \%)$ and lower in shrimp fed Fish diet $(7.3 \%)$. Calculated values for energy expended in exuvia were of $1.5,1.6$, and $2.7 \%$ in shrimp fed Fish, Mix, and Feed diets, respectively, as it was established as proportional to shrimp growth.

The O:N atomic ratio of shrimp fed Fish, Mix, and Feed diets were $16 \pm 5.2,25 \pm 11.6$, and $74 \pm 37.3$, respectively, being significantly higher $(p<0.05)$ for the Feed diet compared to the other, suggesting difference in use of energy substrates among treatments. For fasted individuals, $\mathrm{O}: \mathrm{N}$ atomic ratio was of $25 \pm 16.1$ and did not present statistical difference $(p>0.05)$ in relation to the diets Fish and Mix (Figure 2C).

Table 2. Moisture (\%) and energy ( $\mathrm{J} \mathrm{mg}^{-1}$, dry matter) contents of juvenile Pacific whiteleg shrimp whole body, Litopenaeus vannamei, and shrimp feces, according to the test diets fed to shrimp.

\begin{tabular}{lccc}
\hline & Diet & Moisture $(\%)$ & Energy $\left(\mathrm{J} \mathrm{mg}^{-1}\right)$ \\
\hline Shrimp & Fish & 78.50 & 17.24 \\
& Mix & 75.92 & 16.40 \\
& Feed & 74.15 & 20.72 \\
Feces & Fish & 81.67 & 35.03 \\
& Mix & 81.97 & 11.67 \\
& Feed & 81.55 & 12.30 \\
\hline
\end{tabular}

Fish: chopped fish fillet $(<0.5 \mathrm{~cm})$

Mix: 50-50\% fish and commercial feed. Mean values calculated as 50\% from fish and 50\% from the commercial diet (dry matter basis)

Commercial feed: extruded shrimp feed (Potimar 35 EXT, Guabi Nutrição e Saúde Animal S.A., Campinas, São Paulo, Brazil) 


\section{DISCUSSION}

Energy budget in shrimp may be influenced by different factors such as temperature ( $\mathrm{Su}$ et al., 2010; Wang et al., 2006; Yan et al., 2007), salinity (Rosas et al., 2002; Su et al., 2010; Yan et al., 2007; Ye et al., 2009), life stage (Lemos and Phan, 2001; Maldonado et al., 2009), and nutritional composition of food (Jiménez-Yan et al., 2006; Rosas et al., 2001; Suárez et al., 2009; Wang et al., 2006). The present study observed the influence of different dietary food sources in absolute $\left(\mathrm{kJ} \mathrm{g}^{-1}\right)$ and relative (\%) terms of the variables of the bioenergetics equation $(C=P+R+U+F+E)$ for juvenile $L$. vannamei.

Values between 10 and $19 \%$ of the total ingested energy have been reported to be channeled for growth in juvenile Penaeus monodon and L. vannamei (Table 3). In the present study, similar values (14\%) were observed in shrimp fed Fish and Mix diets, whereas higher energy share to growth (24\%) was observed in shrimp fed Feed diet.
In individuals fed Feed diet, more energy was channeled for growth, as observed in the estimated energy budget (Table 3) as in weight gain. In addition to higher growth of shrimp fed Feed diet, the energy content of whole shrimp tissue was higher than that of shrimp fed Fish or Mix diets, possibly related to a higher amount of body lipid reserves (not determined).

Oxygen consumption rates of shrimp fed different diets did not differ from values previously reported for juvenile L. vannamei (Bett and Vinatea, 2009), whereas some studies have reported different oxygen consumption rate according to different protein, lipids and carbohydrate dietary levels (Maldonado et al., 2009; Rosas et al., 2001). Fasted shrimp showed lower oxygen consumption than fed individuals, resembling the final stage of the post-absorptive period (Carvalho and Phan, 1997; Jobling and Davies, 1980), or due to reduced metabolism in the absence of food.

Table 3. Energy partitioning (\% of ingested energy) between growth $(P)$, metabolism $(R)$, excretion $(U)$, feces $(F)$ and exuvia $(E)$ in shrimp species fed different diets.

\begin{tabular}{|c|c|c|c|c|c|c|c|c|}
\hline Shrimp species & $\begin{array}{l}\text { Weight } \\
(\mathrm{g})\end{array}$ & Diet & $\mathrm{P}$ & $\mathrm{R}$ & $\mathrm{U}$ & $\mathrm{F}$ & $\mathrm{E}$ & Reference \\
\hline Penaeus monodon & $\begin{array}{c}1.15 \\
(0.04)\end{array}$ & commercial feed $^{1}$ & 14.51 & 66.68 & 3.33 & 14.54 & 0.93 & Ye et al. (2009) \\
\hline \multirow[t]{7}{*}{ Litopenaeus vannamei } & $\begin{array}{c}0.486- \\
0.490\end{array}$ & pelleted $\operatorname{diet}^{2}$ & $\begin{array}{l}18.98 \\
(0.23)\end{array}$ & $\begin{array}{l}67.66 \\
(0.35)\end{array}$ & $\begin{array}{c}5.19 \\
(0.06)\end{array}$ & $\begin{array}{c}7.07 \\
(0.40)\end{array}$ & $\begin{array}{c}1.10 \\
(0.07)\end{array}$ & Wang et al.(2006) \\
\hline & $\begin{array}{c}5.36 \\
(0.03)\end{array}$ & commercial feed ${ }^{3}$ & $\begin{array}{l}14.75 \\
(0.33)\end{array}$ & $\begin{array}{l}64.42 \\
(0.50)\end{array}$ & $\begin{array}{c}6.06 \\
(0.05)\end{array}$ & $\begin{array}{l}13.28 \\
(0.43)\end{array}$ & $\begin{array}{c}1.49 \\
(0.19)\end{array}$ & Zhu et al. (2004) \\
\hline & $\begin{array}{c}0.260- \\
0.300\end{array}$ & commercial feed ${ }^{4}$ & $\begin{array}{l}10.38- \\
21.27\end{array}$ & $\begin{array}{c}63.60- \\
78.49\end{array}$ & $\begin{array}{c}3.62- \\
5.37\end{array}$ & $\begin{array}{l}4.17- \\
10.74\end{array}$ & $\begin{array}{c}0.90- \\
1.45\end{array}$ & Yan et al. (2007) \\
\hline & $\begin{array}{c}0.80 \\
(0.00)\end{array}$ & commercial feed $^{5}$ & $\begin{array}{l}14.01 \\
(0.87)\end{array}$ & $\begin{array}{l}69.88 \\
(1.23)\end{array}$ & $\begin{array}{c}7.96 \\
(0.17)\end{array}$ & $\begin{array}{c}7.88 \\
(0.52)\end{array}$ & $\begin{array}{c}0.64 \\
(0.07)\end{array}$ & Su et al. (2010) \\
\hline & 3.5 & Fish $^{6}$ & 13.21 & 70.49 & 7.81 & 7.03 & 1.47 & Present study* \\
\hline & 3.5 & $\operatorname{Mix}^{7}$ & 14.39 & 60.66 & 4.22 & 19.14 & 1.60 & Present study* \\
\hline & 3.5 & commercial feed $^{8}$ & 24.45 & 49.73 & 1.01 & 22.9 & 2.72 & Present study* \\
\hline
\end{tabular}

${ }^{1} 40.50 \%$ crude protein, $8.61 \%$ fat, $10.73 \%$ ash, $9.44 \%$ moisture, $17.02 \mathrm{~kJ} \mathrm{~g}^{-1}$ energy (Yue-hai Feed Company, Guangdong, China)

${ }^{2} 35.18 \%$ crude protein, $7.03 \%$ fat, $10.67 \%$ ash, $6.65 \%$ moisture, $40.47 \%$ nitrogen-free extract, $17.54 \mathrm{~kJ} \mathrm{~g}^{-1}$ energy.

${ }^{3} 41.58 \%$ crude protein, $8.36 \%$ fat, $10.75 \%$ ash, $8.74 \%$ moisture, $19.37 \mathrm{~kJ} \mathrm{~g}^{-1}$ energy.

${ }^{4} 29.13(0.22) \%$ crude protein, $9.55(0.35 \%)$ fat, $11.23(0.22) \%$ ash, $5.46(0.20)$ moisture, $16.65(0.01) \mathrm{kJ} \mathrm{g}^{-1}$ (Fuzhou Haima Feed Co., Ltd., Fuzhou, China).

${ }^{5} 43.39(0.22) \%$ crude protein, $9.74(0.30) \%$ fat, $9.91(0.01) \%$ ash, $8.41(0.06 \%)$ moisture, $19.63(0.52) \mathrm{kJ} \mathrm{g}^{-1}$ energy (Mawei Fishery Feed Co. Ltd., Fujian, China)

${ }^{6}$ chopped Lutjanidae fish fillet $(<0.5 \mathrm{~cm}) .18 .92 \%$ crude protein, $1.01 \%$ fat, $1.18 \%$ ash, $78.85 \%$ moisture, $1.04 \%$ nitrogen-free extract + crude fiber. ${ }^{7} 50 \%$ from fish and 50\% from the commercial feed ${ }^{8}$ (dry matter basis). $22.14 \%$ crude protein, $2.39 \%$ fat, $3.65 \%$ ash, $64.53 \%$ moisture, $7.29 \%$ nitrogen-free extract+crude fiber.

${ }_{8}^{8} 35$ (0.2)\% crude protein, $7.93(0.23) \%$ fat, $13.55(0.86) \%$ ash, $7.27(0.89) \%$ moisture, 36.25\% nitrogen-free extract+crude fiber (Guabi Nutrição e Saúde Animal S.A., Campinas, Brazil)

*estimate 
In general, most of the energy expenditure of an organism is channeled to $R$ (Du Preez et al., 1990; Lemos et al., 2006; Suárez et al., 2009; Wang et al., 2006; Yan et al., 2007; Ye et al., 2009). Although absolute values of $\mathrm{O}_{2}$ consumption did not vary between the tested diets, in relative terms, shrimp fed Fish and Mix diets expended more energy (70.5\% and $60.6 \%$, respectively) than shrimp fed Feed diet (49.7\%). Fish and Mix diets contained 2.3 and 1.6 times more protein than Feed diet on DM basis, and considering them as equivalent ratios, it may indicate higher metabolic cost in individuals fed protein-rich diets (Medland and Beamish, 1985; Rosas et al., 1996).

Ammonia excretion differed between dietary treatments, i.e., in shrimp fed the protein-rich Fish diet, $U$ values was higher, as ammonia excretion increases with increased dietary protein (Gauquelin et al., 2007). Higher ammonia excretion has also been reported in L. vannamei fed high protein or carnivorous diet $(50 \%$ protein) than in shrimp fed high carbohydrate or herbivorous diet (Maldonado et al., 2009; Rosas et al., 2001). In fasted shrimp, ammonia excretion did not differ from shrimp fed the Mix diet, suggesting that during the fasting period shrimp metabolized endogenous reserves to provide energy for vital functions (Comoglio et al., 2004; Rocha et al., 2001; Sánchez-Paz et al., 2007). Energy expenditure in $U$ for $L$. vannamei has been reported as $3-6 \%$ of the total energy intake (Yan et al., 2007; Zhu et al., 2004). In the present study, it represented $1 \%$ of estimated food intake in shrimp fed Feed diet, whereas shrimp fed Fish diet expended $7 \%$ of the total energy intake in $U$. This may probably be due to the higher protein content of the Fish diet and consequent use of protein as main energy source.

Energy expenditure in $F$ in post-larvae and juvenile L. vannamei have been reported to be of 4 to $13 \%$ of the total ingested energy, respectively (Wang et al. 2006; Yan et al., 2007; Zhu et al., 2004). In the present study, higher energy content in $F$ of shrimp fed Mix (19\%) and Feed diets $(23 \%)$ than in those fed Fish diet $(7 \%)$ may indicate how digestible the diets may be, i.e., the more digestible the diet, the less energy in feces.

The O:N atomic ratio has been often used to indicate which substrate is catabolized for energy production (Carvalho and Phan, 1997; Comoglio et al., 2004; Lemos and Phan, 2001; Lemos et al., 2006; Jorge et al., 2007; Rocha et al., 2005), either from exogenous (food) or endogenous (body reserves) sources. Accordingly, the substrate predominantly catabolized by shrimp fed the Fish diet (O:N 16 \pm 5.2$)$ was protein, most likely reflecting the protein-rich food source.
Shrimp fed the Mix diet metabolized a lipid/carbohydrateprotein substrate (O:N 25 \pm 11.6$)$, resulting from the mix of the two food sources. Catabolism in shrimp fed the Feed diet is suggested to be comparatively more upon carbohydrates and/or lipids (O:N 74 \pm 37.3$)$, as the Feed diet provided more fat and carbohydrates than protein as energy sources (44 vs. $35 \%$ as fed basis, respectively). The O:N atomic ratio in fasted shrimp (25 16.1$)$ was similar to shrimp fed the Fish or Mix diets, indicating the endogenous nature of energy substrates for the fasted shrimp. Accordingly, similar O:N atomic ratio values have been reported for juvenile L. vannamei fasted for three days (Comoglio et al., 2004).

The present study suggests the importance of food composition and nutrient balance on the energy budget of juvenile L. vannamei. Accordingly, diet composition may affect energy partitioning in the shrimp physiological processes, resulting in different energy balances and, consequently, affecting important parameters as oxygen consumption, ammonia and feces excretion. In this ways, diets with good nutrient balance may channel more energy to growth.

\section{ACKNOWLEDGMENTS}

The authors are grateful to Mr. L. F. Freitas, Mr. R. H. Ota, Mr. A. E. Nardelli, and Mr. R. E. Kurokawa for their valuable technical assistance during this study.

\section{REFERENCES}

AOAC (Association of Official Analytical Chemists). 2005. Official Methods of Analysis, Gaithersburg, Association of Official Analytical Chemists.

BESERES, J. J., LAWRENCE, A. L. \& FELLOW, R. J. 2005. Variation in fiber, protein, and lipid content of shrimp feedeffects on gut passage times measure in the field. Journal of Shellfish Research, 24, 301-308.

BETT, C. \& VINATEA, L. 2009. Combined effect of body weight, temperature and salinity on shrimp Litopenaeus vannamei oxygen consumption rate. Brazilian Journal of Oceanography, 57, 305-314.

CARVALHO, P. S. M. \& PHAN, V. N. 1997. Oxygen consumption and ammonia excretion of Xiphopenaeus kroyeri Heller (Penaeidae) in relation to mass, temperature and experimental procedures Shrimp oxygen uptake and ammonia excretion. Journal of Experimental Marine Biology and Ecology, 209, 143-156.

COMOGLIO, L. I., GAXIOLA, G., ROQUE, A., CUZON, G. \& AMIN, O. 2004. The effect of starvation on refeeding, digestive enzyme activity, oxygen consumption, and ammonia excretion in juvenile white shrimp Litopenaeus vannamei. Journal of Shellfish Research, 23, 243-249. 
DING, S., WANG, F., DONG, S. \& LI, Y. 2014. Comparison of the respiratory metabolism of juvenile Litopenaeus vannamei cultured in seawater and freshwater. Journal of Ocean University of China, $13,331-337$.

DU PREEZ, H. H., MCLACHLAN, A., MARAIS, J. F. K. \& COCKROFT, A. C. 1990. Bioenergetics of fishes in a high-energy surf-zone. Marine Biology, 106, 1-12.

DUNCAN, A. \& KLEKOWSKI, R. Z. 1975. Parameters of an energy budget. In: GROZINSKI, W., KLEKOWSKI, R. Z. \& DUNCAN, A. (eds.) Methods for ecological bioenergetics (IBP) Handbook No. 24. Oxford: Blackwell Science.

ELLIOTT, J. M. \& DAVISON, W. 1975. Energy equivalents of oxygen consumption in animal energetics. Oecologia, 19, 195-201.

GAUQUELIN, F., CUZON, G., GAXIOLA, G., ROSAS, C., ARENA, L., BUREAU, D. \& COCHARD, J. C. 2007. Effect of dietary protein level on growth and energy utilization by Litopenaeus stylirostris under laboratory conditions. Aquaculture, 271, 439-448.

GNAIGER, E. 1983. Calculation on energetic and biochemical equivalents of respiratory oxygen consumption. In: GNAIGER, E \& FORSTNER, H. (eds). Polarographic Oxygen Sensors. Berlin: Springer.

GRASSHOFF, K., EHRHARDT, M. \& KREMLING，K. 1983. Methods of seawater analysis, Weinheim, Willey-Verlag Chemie.

JIMÉNEZ-YAN, L., BRITO, A. CUZON, G., GAXIOLA, G., GARCÍA, T., TABOADA, G., SOTO, L. A. \& BRITO, R. 2006. Energy balance of Litopenaeus vannamei, postlarvae feed on animal and vegetable protein based compounded feeds. Aquaculture, 260, 337-345.

JOBLING, M. \& DAVIES, P. S. 1980. Effects of feeding on the metabolic rate and the specific dynamic action in Plaice, Pleuronectes platessa L. Journal of Fish Biology, 16, 629-638.

JOBLING, M. 1993. Bioenergetics: feed intake and energy partitioning. In: RANKIN, J. C. \& JENSEN, F. B. (eds.) Fish Ecophysiology. Chapman \& Hall Fish and Fisheries Series, vol 9. Dordrecht, Springer.

JORGE, R. A., LEMOS, D. \& MOREIRA, G. S. 2007. Effect of zinc and benzene on respiration and excretion of mussel larvae (Perna perna) (Linnaeus, 1758) (Mollusca; Bivalvia). Brazilian Journal of Biology, 67, 111-115.

KARZINKIN, G. S. \& TARKOVSKAYA, O. I. 1964. Determination of caloric value of small samples. In: PAVLOSKII, E. N. (ed.) Techniques for the investigation of fish physiology. Israel Program Science Translational, London: Oldbourne Press.

KOROLEFF, F. 1970. Direct determination of ammonia in natural waters as indophenol blue. Conseil Permanent International pour l'Exploration de la Mer, Information on Techniques and Methods for Sea Water Analysis, 3, 122-124.

LEMOS, D. \& PHAN, V. N. 2001. Energy partitioning into growth, respiration, excretion and exuvia during larval development of the shrimp Farfantepenaeus paulensis. Aquaculture, 199, 131-143.

LEMOS, D., NETTO, B. \& GERMANO, A. 2006. Energy budget of juvenile fat snook Centropomus parallelus fed live food. Comparative Biochemistry and Physiology Part A: Molecular \& Integrative Physiology, 144, 33-40.

MALDONADO, C., CUZON, G., GUZMÁN, E., BRITO, R., SOTO, L., ARENA, L. \& GAXIOLA, G. 2009. Effect of an herbivorous diet on energy balance of Litopenaeus vannamei at selected ontogenetic stages. Aquaculture, 296, 123-128.

MAYZAUD, P. \& CONOVER, R. J. 1988. O:N atomic ratio as a tool to describe zooplankton metabolism. Marine Ecology, 45, 289-302.
MEDLAND, T. E. \& BEAMISH, F. W. H. 1985. The influence of diet and fish density on apparent heat increment in rainbow trout, Salmo gairdneri. Aquaculture, 47, 1-10.

PETRUSEWICZ, K. \& MACFADYEN, A. 1970. Productivity of Terrestrial Animals: Principles and Methods, Oxford, Blackwell.

PHAN, V. N., GOMES, V., MORAIS, D. V. \& PASSOS, M. J. A. C. R. 1993. Estudo bioenergético de animais marinhos costeiros. I. Paralonchurus brasiliensis (Perciformes, Sciaenidae). Publicação Especial do Instituto Oceanográfico, 10, 199-215.

ROCHA, A. J. S., GOMES, V., PHAN, V. N., \& PASSOS, M. J. A. C. R. 2001. Variações na demanda de energia metabólica de juvenis de Haemulon steindachneri (Perciformes, Haemulidae) em função da temperatura. Revista Brasileira de Oceanografia, 49, 87-97.

ROCHA, A. J. S., GOMES, V., NGAN, P. V., PASSOS, M. J. A. C. R. \& FURIA, R. R. 2005. Metabolic demand and growth of juveniles of Centropomus parallelus as function of salinity. Journal of Experimental Marine Biology and Ecology, 316, 157-165.

ROSAS, C., SANCHEZ, A., DIAZ, E., SOTO, L. A., GAXIOLA, G. \& BRITO, R. 1996. Effect of dietary protein level on apparent heat increment and post-prandial nitrogen excretion of Penaeus setiferus, $P$. schmitti, $P$. duorarum, and $P$. notialis postlarvae. Journal of the World Aquaculture Society, 27, 92-102.

ROSAS, C., CUZON, G., GAXIOLA, G., LE PRIOL, Y., PASCUAL, C., ROSSIGNYOL, J., CONTRERAS, F., SÁNCHEZ, A. \& VAN WORMHOUDT, A. 2001. Metabolism and growth of juveniles of Litopenaeus vannamei: effect of salinity and dietary carbohydrate levels. Journal of Experimental Marine Biology and Ecology, 259, 1-22.

ROSAS, C., CUZON, G., GAXIOLA, G., PASCUAL, C., TABOADA, G., ARENA, L. \& VAN WORMHOUDT, A. 2002. An energetic and conceptual model of the physiological role of dietary carbohydrates and salinity on Litopenaeus vannamei juveniles. Journal of Experimental Marine Biology and Ecology, 268, 46-67.

SÁNCHEZ-PAZ, A., GARCÍA-CARREÑO, F., HERNÁNDEZLÓPEZ, J., MUHLIA-ALMAZÁN, A. \& YEPIZPLASCENCIA, G. 2007. Effect of short-term starvation on hepatopancreas and plasma energy reserves of the Pacific white shrimp (Litopenaeus vannamei). Journal of Experimental Marine Biology and Ecology, 340, 184-193.

SU, Y., MA, S. \& FENG, C. 2010. Effects of salinity fluctuation on the growth and energy budget of juvenile Litopenaeus vannamei at different temperatures. Journal of Crustacean Biology, 30, 430-434.

SUÁREZ, J. A., GAXIOLA, G., MENDOZA, R., CADAVID, S., GARCIA, G., ALANIS, G., SUÁREZ, A., FAILLACE, J. \& CUZON, G. 2009. Substitution of fish meal with plant protein sources and energy budget for white shrimp Litopenaeus vannamei (Boone, 1931). Aquaculture, 289, 118-123.

WANG, X., MA, S. \& DONG, S. 2006. Effects of water temperature and dietary carbohydrate levels on growth and energy budget of juvenile Litopenaeus vannamei. Chinese Journal of Oceanology and Limnology, 24, 318-324.

YAN, B., WANG, X. \& CAO, M. 2007. Effects of salinity and temperature on survival growth, and energy budget of juvenile Litopenaeus vannamei. Journal of Shellfish Research, 26, 141-146.

YE, L., JIANG, S., ZHU, X., YANG, Q., WEN, W. \& WU, K. 2009. Effects of salinity on growth and energy budget of juvenile Penaeus monodon. Aquaculture, 290, 140-144.

ZHU, C., DONG, S., WANG, F. \& HUANG, G. 2004. Effects of $\mathrm{Na} / \mathrm{K}$ ratio in seawater on growth and energy budget of juvenile Litopenaeus vannamei. Aquaculture, 234, 485-496. 